\title{
EKSPLORASI POTENSI MEDIA ONLINE VIVA.CO.ID DAN METROTVNEWS.COM SEBAGAI PEMBENTUK OPINI PUBLIK Dadi Satria $^{1)}$, Muhammad Adek ${ }^{2)}$

\author{
${ }^{1}$ Fakultas Bahasa dan Seni, Universitas Negeri Padang \\ ${ }^{2}$ Fakultas Bahasa dan Seni, Universitas Negeri Padang \\ email: dadisatria28@gmail.com ${ }^{11}$, marximalize@gmail.com ${ }^{2)}$
}

\begin{abstract}
Penelitian ini bertujuan untuk mengungkapkan potensi media online viva.co.id dan metrotvnews.com sebagai pembentuk opini publik melalui struktur mikro yang dilihat dari penggunaan kata ganti dan pilihan kata. Penelitian ini merupakan penelitian kualitatif dengan menggunakan metode deskriptif. Instrumen penelitian adalah peneliti dengan menggunakan alat bantu lembar pengumpulan data. Data penelitian ini adalah kalimat dan paragraf yang menunjukkan struktur mikro berita viva.co.id dan metrotvnews.com yang memuat topik yang sama. Sumber data penelitian adalah berita media online viva.co.id dan metrotvnews.com periode Januari 2018. Pengumpulan data dilakukan dengan membaca, memahami, dan melakukan pencatatan berita media online viva.co.id dan metrotvnews.com. Pengabsahan data dilakukan dengan teknik triangulasi. Analisis data dilakukan dengan membaca data, mengumpulkan berita yang memuat topik yang sama, mencatat kutipan-kutipan sesuai dengan struktur teks, mengelompokkan kutipan-kutipan tersebut, menjelaskan pendayagunaan, dan menyimpulkan hasil penelitian. Berdasarkan temuan penelitian, kata ganti yang digunakan dalam berita viva.co.id sengaja menciptakan kelompok imajinatif untuk membentuk solidaritas, aliansi, dan perhatian publik serta mengurangi kritik dan oposisi. Berbeda dengan metrotvnews.com yang berusaha menghilangkan jarak dan batas antara komunikator dan pembaca serta membentuk pendapat pribadi menjadi fikiran bersama. Berdasarkan struktur stilistik, viva.co.id membangun berita melalui pilihan kata dan kalimat yang baik agar pembaca mudah memahami informasi yang disampaikan dan menciptakan kesan positif dari setiap pemberitaan. Metrotvnews.com lebih cenderung mengungkapkan fakta secara terbuka kepada pembaca tanpa menyembunyikan realita melalui pilihan kata.
\end{abstract}

Kata Kunci: berita, media online, viva.co.id, metrotvnews.com, opini publik

\section{PENDAHULUAN}

Kebutuhan Informasi secara cepat dan akurat merupakan sebuah kebutuhan esensial masyarakat melalui media massa. Melalui informasi manusia dapat memperluas pandangan dan wawasannya, serta lebih meningkatkan kedudukan dan peranannya dalam masyarakat. Untuk mendapatkan informasi manusia dibatasi oleh panca inderanya, karena itu dibutuhkan suatu media sebagai sarana komunikasi yang dikenal dengan media massa. Liliweri (1996:42) menjelaskan bahwa salah satu peranan media massa dalam kehidupan manusia adalah untuk 
memberikan informasi dan membantu mengetahui secara jelas segala ihwal tentang dunia sekelilingnya.

Saat ini terdapat jenis media massa yang telah akrab dengan masyarakat seperti media cetak, media elektronik, dan media online. Media online merupakan media massa generasi ketiga. Media online adalah media komunikasi massa yang tersaji secara online di internet, seperti versi online surat kabar atau majalah dan portal berita online atau situs berita (Romli, 2009: 16). Kehadiran media online telah membawa perubahan baru dalam perilaku komunikasi, baik komunikasi personal, komunikasi kelompok, maupun komunikasi massa.

Pemberitaan pada media massa tidak terlepas dari beragam kepentingan, termasuk kepentingan politik. Oleh sebab itu, munculah sebuah anggapan bahwa berita yang disampaikan bukanlah fakta yang objektif, melainkan fakta yang telah dikontruksi oleh media atau penulisnya/ wartawan dengan latar belakang kepentingan tertentu (Sudibyo, 2001: 31). Dengan demikian, tidak sedikit masyarakat yang merasa bimbang untuk menilai kebenaran dalam penyampaian informasi sehingga dapat memberikan dampak negatif pada pola pikir masyarakat.

Berdasarkan permasalahan tersebut perlu rasanya dilakukan pengkajian sebagai upaya untuk mengetahui maksud tersembunyi dari berita yang dituliskan pada media online. Peneliti memilih media online viva.co.id dan metrotvnews.com sebagai objek penelitian mengingat tingginya akses masyarakat dewasa ini terhadap pemberitaan yang memanfaatkan media online. Selain itu, kedua media online ini dipegang oleh dua politisi yang cukup berpengaruh di Indonesia.

Pengungkapan ideologi pada kedua media online ini menggunakan analisis wacana kritis model Teun A. Van Dijk. Melalui model ini dapat dijelaskan berbagai masalah yang kompleks dan rumit dengan menganalisis teks semata. Selain itu, menurut Eriyanto (2009:224) model Van Dijk juga melihat struktur sosial, dominasi dan kelompok kekuasaan yang ada dalam masyarakat dan bagaimana kognisi/pikiran dan kesadaran yang membentuk dan berpengaruh terhadap teks tertentu. Tarigan (1987: 27) mengemukakan bahwa wacana adalah satuan bahasa yang paling lengkap, lebih tinggi dari klausa dan kalimat, memiliki kohesi dan koherensi yang baik, mempunyai awal dan akhir yang jelas, berkesinambungan, dan dapat disampaikan secara lisan atau tertulis. Berdasarkan struktur generik dan fiturfitur bahasanya, wacana dapat dikelompokkan menjadi wacana naratif, wacana deskriptif dan wacana argumentatif. Wacana naratif dapat dibagi menjadi beberapa genre seperti: narasi, rekon (recount), anekdot, spoof, dan berita. Dengan demikian berita merupakan salah satu objek kajian wacana. 
Berita dilihat dari sisi jurnalistik menurut Ermanto (2001:6) yaitu peristiwa, kejadian, aspek-aspek kehidupan manusia yang dianggap baru, dianggap penting, mempunyai daya tarik dan mengandung keingintahuan pembaca atau masyarakat. Kriteria tentang nilai berita ini sekarang sudah lebih disederhanakan dan sistematik (Kusumaningrat, 2005:60). Unsurunsurnya antara lain aktualitas (timeliness), kedekatan (proximity), keterkenalan (prominence), dampak (consequence), dan menarik minat orang (human interest). Dengan demikian dapat disimpulkan bahwa berita merupakan hasil kerja jurnalistik berupa informasi yang berisi fakta, ide, ataupun opini yang menarik, aktual dan akurat yang dimuat di berbagai media.

Teks merupakan jalan menuju pemahaman terhadap sebuah bahasa karena berfungsi dan sedang melaksanakan tugas tertentu dalam konteks situasi. Seperti yang diungkapkan Halliday dan Ruqaiyah (1992:77) bahwa teks merupakan ungkapan pernyataan suatu kegiatan sosial yang bersifat verbal. Senada dengan itu, Mahsun (2014: 1) menjelaskan bahwa bahasa yang digunakan dalam tujuan sosial tertentu akan melahirkan teks. Jadi dapat disimpulkan bahwa berita merupakan salah satu jenis teks sebagai hasil kerja jurnalistik yang memuat informasi sebagai rekontruksi realitas sosial kepada masyarakat.
Berita utama atau yang disebut dengan headline news adalah informasi atau berita yang dianggap terpenting dari seluruh informasi yang disajikan oleh suatu media massa. Berita yang paling penting, menarik dan sesuai dengan kebutuhan khalayak biasanya ditempatkan pada urutan teratas sebagai salah satu strategi untuk menarik minat pembaca. Berita utama didefinisikan oleh Djunaedy (1990: 29) sebagai suatu berita yang dianggap paling layak untuk dimuat di halaman depan, dengan judul yang menarik perhatian dan menggunakan tipe huruf lebih besar dari suatu surat kabar.

Di samping media komunikasi yang telah terlebih dahulu akrab dan diterima khalayak seperti media cetak dan media elektronik, media online kini telah menjadi salah satu media komunikasi yang mulai mendapat banyak perhatian dari masyarakat. Menurut Hamdan (2014: 171-183) media online adalah gagasan baru dalam bermedia, namun media baru masih mengikut pada media lama dan bahkan sering memanfaatkan media lama sebagai tolak ukur dalam segi isi yang diterapkan di internet.

Berita yang dimuat dalam media massa termasuk media online tentu saja tidak dapat dilepaskan dari ideologi yang dipegang media tersebut. Menurut Aart Van Zoest (dalam Sobur, 2004:70), sebuah teks tidak pernah lepas dari ideologi dan memiliki kemampuan untuk memanipulasi pembaca ke arah suatu ideologi. Melalui hal ini dapat kita lihat potensi 
kekuatan kedua media dalam menggiring opini publik.

Upaya mengeksplorasi pembentuk opini publik dalam berita media online viva.co.id dan metrotvnews.com dilakukan menggunakan analisis wacana kritis model Teun A. Van Dijk. Pada tataran linguistik, Van Dijk memanfaatkan struktur teks untuk mengetahui maksud dan memaknai suatu teks. Struktur teks yang dimaksud meliputi struktur yang saling mendukung, yaitu struktur makro, superstruktur, dan struktur mikro. Akan tetapi dalam penelitian ini, upaya eksplorasi kekuatan kedua media dalam membentuk opini public diungkap melalui struktur mikro berupa unsur sintaksis dan stilistik. Dalam unsur sintaksis hanya akan dilihat penggunaan kata ganti dan dari unsur stilistik akan dilihat pilihan kata.

\section{Metode Penelitian}

Jenis penelitian ini adalah penelitian kualitatif dengan metode deskriptif. Penelitian kualitatif adalah penelitian yang menghasilkan prosedur analisis yang tidak menggunakan prosedur analisis statistik atau cara kuantifikasi lainnya. Metode deskriptif dimaksudkan untuk mendeskripsikan dengan sejelas-jelasnya tentang objek yang diteliti, serta menggambarkan data secara keseluruhan, sistematis dan akurat.

Data penelitian ini adalah berita pada dua media online yang berbeda yang memuat topik yang sama. Sumber data penelitian ini adalah berita utama pada media online viva.co.id dan metrotvnews.com. Berita yang dipilih adalah edisi bulan Januari 2018. Hal ini disebabkan karena Januari merupakan awal tahun dengan banyak isu-isu hangat seputaran dunia ekonomi, politik, sosial, budaya dan lain-lain yang dibicarakan sebagai bentuk harapan di tahun yang baru. Dengan demikian, pemilihan pengumpulan data didasari dari kebutuhan penelitian mengenai data berupa berita pada media online yang berbeda untuk dapat dibandingkan dan diungkap potensi kedua media online ini dalam menggiring opini publik.

Metode yang digunakan dalam penelitian ini adalah metode simak. Metode simak dilakukan dengan teknik simak bebas libat cakap dan teknik catat. Teknik simak yang dimaksudkan di sini adalah simak tulis. Teknik pengabsahan data dalam penelitian ini adalah teknik triangulasi. Analisis data dalam penelitian ini dilakukan dengan cara: (1) membaca data yang telah terkumpul secara keseluruhan, (2) mencatat kutipan-kutipan sesuai topik yang dibahas berdasarkan lembaran pencatatan, (3) mengelompokkan kutipan berdasarkan struktur teks pada dalam berita online viva.co.id dan metrotvnews.com, (4) menentukan struktur teks berdasarkan format pengumpulan data, (5) menemukan ideologi media berdasarkan struktur mikro, dan (6) menarik kesimpulan.

\section{Hasil dan Pembahasan}




\section{Berita Media Online Viva.co.id Dilihat dari Penggunaan Kata Ganti}

Berita media online viva.co.id dilihat melalui struktur sintaksis difokuskan pada penggunaan kata ganti. Berikut rincian pemakaian kata ganti dalam berita media online viva.co.id.

Tabel Rincian Struktur Sintaksis (Kata Ganti) Berita Viva.co.id
Penggunaan kata ganti atau pronominal yang ditemukan dalam berita pada media online viva.co.id berjumlah 389 pronominal dengan rincian pronominal persona orang pertama tunggal 32 pronominal dan persona orang pertama jamak 35 pronominal. Berikutnya, persona orang ketiga tunggal 151 pronominal dan persona orang ketiga jamak 20 pronominal. Selanjutnya pronominal penunjuk umum 148 pronominal, pronominal penunjuk tempat 1 pronominal, dan pronominal penanya orang 2 pronominal.

\begin{tabular}{|c|c|c|c|c|c|}
\hline $\begin{array}{l}\mathbf{N} \\
\mathbf{0}\end{array}$ & \multicolumn{3}{|c|}{ Kata Ganti } & Jumlah & \multirow{4}{*}{$\begin{array}{l}\text { pronominal penanya orang } 2 \\
\text { pronominal. } \\
\text { Penggunaan kata ganti dalam } \\
\text { sebuah berita memiliki arti dan makna } \\
\text { sesuai dengan konteks yang dibangun } \\
\text { wartawan. Kata ganti dijelaskan oleh } \\
\text { Eriyanto (2009:253-254) sebagai }\end{array}$} \\
\hline \multirow[t]{8}{*}{1} & \multirow[t]{8}{*}{$\begin{array}{l}\text { Perso } \\
\text { na }\end{array}$} & $\begin{array}{l}\text { Orang pertama } \\
\text { tunggal }\end{array}$ & Saya & 32 & \\
\hline & & \multirow[t]{2}{*}{$\begin{array}{l}\text { Orang pertama } \\
\text { jamak }\end{array}$} & $\begin{array}{l}\text { Kam } \\
\text { i }\end{array}$ & 20 & \\
\hline & & & Kita & 15 & \\
\hline & & \multirow[t]{4}{*}{$\begin{array}{l}\text { Orang ketiga } \\
\text { tunggal }\end{array}$} & -nya & 90 & \multirow{5}{*}{$\begin{array}{l}\text { menciptakan suatu komunitas } \\
\text { imajinatif. Kata ganti merupakan alat } \\
\text { yang dipakai oleh komunikator untuk } \\
\text { menunjukkan dimana posisi seorang } \\
\text { dalam wacana. Berikut dipaparkan } \\
\text { contoh penggunaan kata ganti dalam } \\
\text { berita media online viva.co.id. } \\
\text { Identitas data: III/GPDP/3Jan2018 }\end{array}$} \\
\hline & & & la & 18 & \\
\hline & & & Dia & 41 & \\
\hline & & & $\begin{array}{l}\text { Belia } \\
\mathrm{u}\end{array}$ & 2 & \\
\hline & & $\begin{array}{l}\text { Orang ketiga } \\
\text { jamak }\end{array}$ & $\begin{array}{l}\text { Mer } \\
\text { eka }\end{array}$ & 20 & \\
\hline \multirow[t]{3}{*}{2} & \multirow[t]{3}{*}{$\begin{array}{l}\text { Penun } \\
\text { juk }\end{array}$} & Umum & Ini & 75 & \multirow{5}{*}{$\begin{array}{r}\text { Kata ganti : 1). "Kami, pimpinan dari } \\
\text { tiga partai tadi } \\
\text { membahas } \\
\text { menyempurnakan seleksi } \\
\text { calon-calon gubernur } \\
\text { dan wakil gubernur. }\end{array}$} \\
\hline & & & Itu & 73 & \\
\hline & & Tempat & \begin{tabular}{|l} 
di \\
situ \\
\end{tabular} & 1 & \\
\hline 3 & $\begin{array}{l}\text { Penan } \\
\text { ya }\end{array}$ & Orang & $\begin{array}{l}\text { Siap } \\
\text { a }\end{array}$ & 2 & \\
\hline \multicolumn{4}{|c|}{ Total } & 389 & \\
\hline
\end{tabular}


hingga detik terakhir," kata Prabowo di kediamannya, Jakarta.

2). Hal yang sama diungkapkan Sohibul Iman. "Soal Jatim, hari ini kami bahas kembali. Tapi, kami belum juga sampai ke kesimpulan bersama. Karena itu, kami akan bahas kembali," ujar Sohibul.

Salah satu penggunaan kata ganti dalam berita utama viva.co.id yang mencerminkan ideologi media adalah penggunaan kata ganti persona orang pertama jamak kami. Melalui penggunaan kata ganti kami dapat dilihat dimana posisi wartawan dalam sebuah berita. Sebagaimana yang diungkapkan Eriyanto (2009: 254) bahwa kata ganti merupakan alat yang dipakai oleh komunikator untuk menunjukkan dimana posisi seseorang dalam wacana. Lebih lanjut Eriyanto menjelaskan bahwa pemakaian kata ganti jamak seperti "kami”, mempunyai implikasi menumbuhkan solidaritas, aliansi, perhatian publik, serta mengurangi kritik dan oposisi (hanya) kepada diri sendiri. Dengan demikian, ideologi media ini tercermin dari sikap viva.co.id yang sengaja menciptakan kelompok imajinatif dalam pemberitaan untuk membentuk solidaritas, aliansi, dan perhatian publik serta mengurangi kritik dan oposisi.

\section{Berita Media Online Viva.co.id Dilihat dari Pilihan Kata}

\begin{abstract}
Dalam struktur stilistik dapat dilihat bagaimana media online membangun pemberitaan dengan melakukan pemilihan kata. Pemilihan kata tidak semata hanya karena kebetulan, akan tetapi secara ideologi menunjukkan pemahaman terhadap fakta. Hal tersebut berkaitan dengan apa yang diungkapkan oleh Eriyanto (2009:255) bahwa pada dasarnya elemen ini menandakan bagaimana seseorang melakukan pemilihan kata atas berbagai kemungkinan kata yang tersedia. Berikut contoh pilihan kata yang digunakan viva.co.id dalam berita utamanya.
\end{abstract}

Identitas berita :

V/HDMK/07Jan2018

Pilihan kata : (1) Generasi muda Partai
Golkar mendatangi
kediaman Presiden ke-3
yang juga tokoh senior
Partai r Golkar,
Baharuddin
Habibie. (2) Salah satu kader muda, Ace Hasan Sadzily mengatakan, pertemuan dengan Habibie diharap bisa memberi angin segar bagi konflik partai berlambang pohon beringin ini.

Pemilihan kata yang digunakan
dalam berita utama di atas
menunjukkan pemaknaan wartawan
terhadap peristiwa/ berita yang


disampaikan. Kata generasi muda yang digunakan oleh viva.co.id memberikan kesan menghilangkan kelompokkelompok atau kubu-kubu dalam tubuh partai Golkar. Sementara pilihan kata memberi angin segar yang digunakan dalam berita di atas memiliki konotasi yang halus sebagai bentuk harapan yang ditujukan kepada Habibie.

\section{Contoh lainnya dapat dilihat pada penggunaan kata kasus} terbunuhnya warga, sabetan benda tajam, tersangka, pelaku memukuli korban hingga jatuh dan lain-lain merupakan kata-kata yang cukup halus meskipun informasi yang disampaikan berkaitan dengan kriminalitas. Eriyanto (2009:255) mengungkapkan bahwa pada dasarnya pemilihan kata menandakan bagaimana seseorang melakukan pemilihan kata atas berbagai kemungkinan kata yang tersedia. Pilihan kata yang dipakai menunjukkan sikap dan ideologi tertentu. Peristiwa sama dapat digambarkan dengan pilihan kata yang berbeda-beda. Dengan demikian dapat disimpulkan bahwa viva.co.id selalu mempertimbangkan setiap kata yang digunakan agar pembaca mudah memahami informasi yang disampaikan dan menciptakan kesan positif dari setiap pemberitaannya.

\section{Berita Media Online}

\section{Metrotvnews.com Dilihat dari Penggunaan Kata Ganti}

Berdasarkan kajian sintaksis
berita, ditemukan beberapa
penggunaan kata ganti yang

mencerminkan ideologi metrotvnews.com. Kata ganti dijelaskan oleh Eriyanto (2009:253254) sebagai elemen memanipulasi bahasa dengan menciptakan suatu komunitas imajinatif. Kata ganti yang digunakan juga memperlihatkan posisi seseorang dalam pemberitaan. Berikut rincian kata ganti yang digunakan oleh media online metrotvnews.com.

Tabel 9. Rincian Struktur Sintaksis (Kata Ganti) Berita Metrotvnews.com

\begin{tabular}{|c|c|c|c|c|}
\hline No & & Kata Ganti & & Jumlah \\
\hline \multirow[t]{10}{*}{1} & \multirow[t]{10}{*}{ Persona } & $\begin{array}{l}\text { Orang } \\
\text { pertama } \\
\text { tunggal }\end{array}$ & Saya & 32 \\
\hline & & \multirow{2}{*}{$\begin{array}{l}\text { Orang } \\
\text { pertama } \\
\text { jamak }\end{array}$} & Kami & 10 \\
\hline & & & Kita & 36 \\
\hline & & \multirow{2}{*}{$\begin{array}{l}\text { Orang } \\
\text { kedua } \\
\text { tunggal }\end{array}$} & Anda & 1 \\
\hline & & & kamu & 2 \\
\hline & & \multirow{4}{*}{$\begin{array}{l}\text { Orang } \\
\text { ketiga } \\
\text { tunggal }\end{array}$} & -nya & 78 \\
\hline & & & la & 3 \\
\hline & & & Dia & 50 \\
\hline & & & beliau & 5 \\
\hline & & $\begin{array}{l}\text { Orang } \\
\text { ketiga } \\
\text { jamak }\end{array}$ & mereka & 12 \\
\hline \multirow[t]{6}{*}{2} & \begin{tabular}{|l} 
Penunju \\
$\mathrm{k}$
\end{tabular} & Umum & Ini & 68 \\
\hline & & & Itu & 52 \\
\hline & & \multirow{3}{*}{ Tempat } & di situ & 2 \\
\hline & & & di sini & 4 \\
\hline & & & ke sini & 1 \\
\hline & & Ihwal & begini & 1 \\
\hline
\end{tabular}




\begin{tabular}{|c|c|c|c|c|}
\hline \multirow[t]{3}{*}{3} & \multirow[t]{3}{*}{ Penanya } & Waktu & kapan & 2 \\
\hline & & \multirow{2}{*}{ Tempat } & dimana & 1 \\
\hline & & & kemana & 1 \\
\hline \multicolumn{4}{|c|}{ Tot } & 361 \\
\hline
\end{tabular}

Penggunaan kata ganti atau pronominal yang ditemukan dalam berita utama pada media online metrotvnews.com berjumlah 361 pronominal dengan rincian pronominal persona orang pertama tunggal 32 pronominal dan persona orang pertama jamak 46 pronominal. Berikutnya, persona orang kedua tunggal 3 pronominal, persona orang ketiga tunggal 136 pronominal dan persona orang ketiga jamak 12 pronominal. Selanjutnya pronominal penunjuk umum 120 pronominal, pronominal penunjuk tempat 7 pronominal, dan pronominal penunjuk ihwal 1 pronominal. Pronominal penanya waktu 2 pronominal dan pronominal penanya tempat 2 pronominal. Berikut contoh kata ganti yang digunakan metrotvnews.com dalam berita.

Identitas data : M/AABP/01Jan2018 antara komunikator dengan khalayak sengaja dihilangkan untuk menunjukkan sikap komunikator juga menjadi sikap komunitas secara keseluruhan. Kata ganti ini memperlihatkan bahwa wartawan berada pada posisi pembaca dalam melihat sebuah peristiwa atau informasi yang disampaikan dalam berita. Eriyanto (2009:254) mengungkapkan bahwa pemakaian kata ganti "kita" menciptakan perasaan bersama di antara wartawan dan khalayak; karena pendapat khalayak diwakili oleh wartawan. Kata ganti "kita" dipakai untuk menunjukkan tidak ada batas antara wartawan/komunikator dengan khalayak. Dengan demikian dapat disimpulkan bahwa melalui penggunaan kata ganti, metrotvnews.com menghilangkan batas dan jarak antara komunikator dengan pembaca dan membentuk pandangan pribadi menjadi pandangan bersama.

\section{Berita Media Online}

\section{Metrotvnews.com Dilihat dari Pilihan} Kata

Kata ganti : 1). "Besok kita ${ }^{1}$ perkirakan menjadi aruselpailiknan kata tidak semata

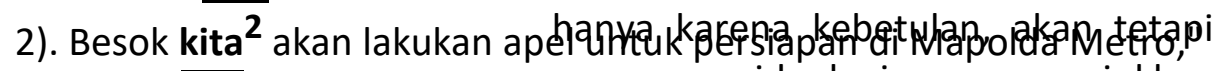
Tito kepada wartawan di Mapolda Metro Jaya, Jumagi (1/1/2016) idukkan pemahaman terhadap fakta. Melalui struktur stilistik dapat dilihat

Salah satu penggunaan kata ganti yang mencerminkan maksud media adalah penggunaan kata ganti orang pertama jamak kita yang dominan digunakan dalam berita. Kata ganti kita mengartikan bahwa batas bagaimana media membangun pemberitaan dengan melakukan pemilihan kata. Eriyanto (2009:255) menyebutkan pada dasarnya elemen ini menandakan bagaimana seseorang melakukan pemilihan kata atas 
berbagai kemungkinan kata yang tersedia.

\section{Sebagaimana dalam berita metrotvnews.com ini dapat dilihat kecenderungan mengungkapkan sesuatu sesuai dengan kondisi dan realita yang ditemukan sehingga lebih terkesan terbuka dalam setiap pemberitaannya. Sebagai contohnya dapat dilihat pada kutipan berikut.}

Identitas berita :

M/KPBM/12Jan2018

\section{Pilihan kata : (1) KT, bocah 12 tahun yang diduga dipukul Marinir kini terbaring di Rumah Sakit Prikasih, Pondok Labu, Jakarta Selatan.}

(2) "Dia sudah diinterogasi saya lihat, sudah berdarah, telanjang cuma pakai celana dalam," jelasnya.

Pemilihan kata yang digunakan dalam berita di atas menunjukkan pemaknaan wartawan terhadap peristiwa/ berita yang disampaikan. Penggunaan kata diduga dipukul dan berdarah, telanjang cuma pakai celana dalam dalam pemberitaannya memperlihatkan bahwa realita ditampilkan sebagaimana adanya walaupun menimbulkaan kesan agak vulgar. Pilihan kata lainnya dapat dilihat pada kalimat memaki-maki korban dengan kata-kata kotor dan memukul korban berkali-kali dan juga menendang korban, korban mengalami luka di kaki akibat tendangan, gigi rahang bengkak, enggak bisa ngunyah akibat pukulan di dekat telinga dan tangan bengkak dan lain-lain merupakan penggambaran kondisi sebenarnya tanpa ada hal yang disembunyikan oleh wartawan. Dengan demikian dapat disimpulkan bahwa metrotvnews.com cenderung mengungkapkan fakta secara terbuka kepada pembaca tanpa menyembunyikan realita melalui pilihan kata.

\section{Pembahasan}

\section{Berita Media Online Viva.co.id Dilihat dari Struktur Sintaksis dan Stilistik.}

Kajian berita utama pada media online viva.co.id dilihat dari struktur sintaksis yang difokuskan pada penggunaan kata ganti. Kata ganti digunakan untuk berbagai maksud dan tujuan tergantung konteks dan konsep yang sengaja dibentuk. Setiap kata ganti yang digunakan menyiratkan makna yang beragam dan tujuan yang berbeda sesuai dengan konteks yang dihadirkan oleh wartawan.

Seperti pemakaian kata ganti saya, anda, kami, atau kita dalam teks berita jelas menempatkan pembaca menjadi bagian yang integral dalam keseluruhan teks. Bagian yang integral ini bukan hanya khalayak dipandang ada, tetapi juga secara tidak langsung memperhitungkan keberadaan pembaca. Kehadiran yang diperhitungkan itu bisa untuk menarik 
dukungan, menekankan, atau untuk menarik simpati dari pembaca atau sekedar meyakinkan. Di sini terjadi negosiasi antara wartawan sebagai penulis dengan khalayak sebagai pembaca.

Berdasarkan kajian sintaksis yang digunakan dalam berita utama viva.co.id, salah satu kata ganti yang dominan digunakan viva.co.id adalah kata ganti orang pertama jamak "kami". Penggunaan kata ganti kami selain menciptakan kelompok imajinatif juga merupakan sebuah

bentuk manipulasi bahwa kalimat berita yang dihasilkan mampu membentuk implikasi dan tujuan tertentu. Dengan demikian, viva.co.id menggunakan kata ganti untuk menciptakan kelompok imajinatif dalam pemberitaan untuk membentuk solidaritas, aliansi dan perhatian publik serta mengurangi kritik dan oposisi.

Struktur teks kedua yang digunakan dalam menemukan ideologi dalam berita pada media online viva.co.id adalah struktur stilistik. Dalam struktur stilistik dapat dilihat bagaimana media online membangun pemberitaan dengan melakukan pemilihan kata. Pemilihan kata tidak semata hanya karena kebetulan, akan tetapi secara ideologi menunjukkan pemahaman terhadap fakta. Sebagaimana dalam berita viva.co.id, informasi disampaikan melalui pemilihan kata yang matang.

Hal tersebut berkaitan dengan apa yang diungkapkan oleh Eriyanto
(2009:255) bahwa pada dasarnya elemen ini menandakan bagaimana seseorang melakukan pemilihan kata atas berbagai kemungkinan kata yang tersedia. Sebagai contohnya dapat dilihat pada penggunaan kata kasus terbunuhnya warga, sabetan benda tajam, tersangka, pelaku memukuli korban hingga jatuh dan lain-lain merupakan kata-kata yang cukup halus meskipun informasi yang disampaikan berkaitan dengan kriminalitas. Dengan demikian, dapat disimpulkan bahwa viva.co.id selalu mempertimbangkan setiap kata yang digunakan agar pembaca mudah memahami informasi yang disampaikan dan menciptakan kesan positif dari setiap pemberitaannya.

Berdasarkan kajian struktur sintaksis dan struktur stilistik berita media online viva.co.id di atas, maka dapat disimpulkan bahwa berita utama media online viva.co.id merefleksikan kepentingan kelompok dominan dalam pemberitaannya. Berita utama media online viva.co.id menggambarkan beragam kepentingan sebagai sarana pembentuk opini publik yang mewakili pemilik media massa.

\section{Berita Media Online}

\section{Metrotvnews.com Dilihat dari Struktur Sintaksis dan Stilistik.}

Kajian berita pada media online metrotvnews.com dilihat dari struktur sintaksis yang difokuskan pada penggunaan kata ganti memperlihatkan bahwa setiap kata ganti yang digunakan memiliki maksud 
tertentu sesuai dengan konsep dan konteks yang dibangun dalam pemberitaannya. Kata ganti dijelaskan oleh Eriyanto (2009:253-254) sebagai elemen memanipulasi bahasa dengan menciptakan suatu komunitas imajinatif. Kata ganti yang digunakan juga memperlihatkan posisi seseorang dalam pemberitaan.

Berdasarkan kajian sintaksis berita metrotvnews.com, salah satu kata ganti yang dominan digunakan adalah kata ganti orang pertama jamak kita. Penggunaan kata ganti kita mengartikan bahwa batas antara komunikator dengan khalayak sengaja dihilangkan untuk menunjukkan sikap komunikator juga menjadi sikap komunitas secara keseluruhan. Kata ganti ini memperlihatkan bahwa wartawan berada pada posisi pembaca dalam melihat sebuah peristiwa atau informasi yang disampaikan dalam berita. Dengan demikian, dapat disimpulkan bahwa melalui penggunaan kata ganti, metrotvnews.com menghilangkan batas dan jarak antara komunikator dengan pembaca dan membangun opini individu menjadi pikiran bersama.

Struktur teks selanjutnya dalam berita media online metrotvnews.com adalah struktur stilistik. Melalui struktur stilistik dapat dilihat bagaimana media membangun pemberitaan dengan melakukan pemilihan kata. Eriyanto (2009:255) menyebutkan pada dasarnya elemen ini menandakan bagaimana seseorang melakukan pemilihan kata atas berbagai kemungkinan kata yang tersedia. Pemilihan kata tidak semata hanya karena kebetulan, akan tetapi secara ideologi menunjukkan pemahaman terhadap fakta. Sebagaimana dalam berita utama metrotvnews.com ini dapat kita lihat kecenderungan mengungkapkan sesuatu sesuai dengan kondisi dan realita yang ditemukan sehingga lebih terkesan terbuka dalam setiap pemberitaannya.

Sebagai contohnya dapat dilihat pada penggunaan kata memaki-maki korban dengan kata-kata kotor dan memukul korban berkali-kali dan juga menendang korban, korban mengalami luka di kaki akibat tendangan, gigi rahang bengkak, enggak bisa ngunyah akibat pukulan di dekat telinga dan tangan bengkak dan lain-lain merupakan penggambaran kondisi sebenarnya tanpa ada hal yang disembunyikan oleh wartawan. Dengan demikian, dapat disimpulkan bahwa metrotvnews.com cenderung mengungkapkan fakta secara terbuka kepada pembaca tanpa menyembunyikan realita menggunakan pilihan kata.

\section{Simpulan}

Berdasarkan temuan penelitian yang diuraikan di atas, dapat disimpulkan bahwa terdapat perbedaan kekuatan dalam membangun opini publik antara viva.co.id dan metrotvnews.com berdasarkan struktur sintaksis dan stilistik. Berdasarkan struktur sintaksis yang difokuskan pada penggunaan kata 
ganti, viva.co.id dan metrotvnews.com memiliki strategi yang berbeda sebagai usaha untuk membentuk opini publik melalui konteks yang dibangun dalam pemberitaan. Viva.co.id menggunakan kata ganti untuk menciptakan kelompok imajinatif dalam pemberitaan untuk membentuk solidaritas, aliansi, dan perhatian publik serta mengurangi kritik dan oposisi. Berbeda dengan metrotvnews.com yang mencoba menghilangkan jarak dan batas antara komunikator dengan pembaca atau memanipulasi pendapat pihak tertentu sehingga menjadi pendapat bersama.

Berdasarkan struktur stilistik dapat dilihat bahwa viva.co.id lebih cenderung mempertimbangkan setiap kata agar pembaca mudah memahami informasi yang disampaikan dan menciptakan kesan positif dari setiap pemberitaan. Sementara itu, metrotvnews.com cenderung mengungkapkan fakta secara terbuka kepada pembaca tanpa menyembunyikan realita menggunakan pilihan kata.

\section{Referensi}

Djunaedy, Kurniawan. (1990).

Ensiklopedia Pers Indonesia. Jakarta:

Gramedia Pustaka Utama.

Eriyanto. (2009). Analisis Wacana

Pengantar Analisis Teks Media.

Yogyakarta:
Ermanto. (2001). "Berita dan Fotografi". Padang: FBS UNP.

Halliday, M. A. K. dan Ruqaiyah, Hasan. (1992). Bahasa, Konteks, dan Teks. Yogyakarta: Gadjah Mada University Press.

Hamdan. (2014). "Analisis Framing Berita Perseteruan KPK dan Polri di Media Kompas.com dan Vivanews.com" (eJurnal IImu Komunikasi, Nomor 4, Tahun 2014, Halaman 171-183). Kalimantan: Universitas Mulawarman.

Kusumaningrat, Hikmat. (2005).

Jurnalistik Teori dan Praktek. Bandung: Remaja Rosda Karya.

Liliweri, Alo. (1996). Memahami Peran Komunikasi dalam Masyarakat.

Bandung: Rosda Karya.

Mahsun. (2014). Teks dalam

Pembelajaran Bahasa Indonesia

Kurikulum 2013. Jakarta: Raja

Grafindo Persada.

Romli, Asep. (2009). Jurnalistik Praktis. Bandung: Remaja Rosdakarya.

Sobur, Alex. (2004). Analisis Teks

Media. Bandung: Remaja Rosdakarya.

Sudibyo, Agus. (2001). Politik Media dan Pertarungan Wacana. Yogyakarta: LKIS.

LkiS. 
SEMINAR NASIONAL BULAN BAHASA 1

"MENDUNIAKAN BAHASA DAN SASTRA INDONESIA"

FAKULTAS PENDIDIKAN BAHASA DAN SENI

UNIVERSITAS PGRI SEMARANG

Semarang, 7 NOVEMBER 2018

Tarigan, Henry Guntur. (1987). Teknik

Pengajaran Keterampilan Berbahasa.

Bandung:Angkasa. 